\title{
Theme II: The Internationalisation of Capital
}

\section{Implications of the employment of women in the new manufacturing industries in LDCs}

There has been rapid growth in recent years in the employment of women in the new manufacturing industries in a number of less developed countries (LDCs). Two policies favoured by international development agencies - the setting up of Free Production Zones, and the promotion of 'informal sector' activities - have encouraged this expansion, the implications of which for women was the main concern of these papers. Has the employment of women in new manufacturing industries improved their status, helped them to be more independent, put them on a more equal footing with men in the work force, as those who place great stress on the provision of job opportunities for women have hoped? Can the low pay and arduous working conditions which are generally admitted to characterise these jobs be offset against a transformation of certain traditional patterns and modes of behaviour that condemn women to a secondary role in a male dominated society?
The plenary paper ${ }^{1}$ examined the new manufacturing industries within the context of the international process of capital accumulation, and proposed a framework in which its effects might be evaluated. Complementing this were four detailed case studies: on the 'informal sector' in Calcutta; on electronics factories in the Free Production Zone, Penang, Malaysia; on a textile factory in Singapore; and on the Mexico border industries. Related papers covered the historical development of women's participation in the labour force in Puerto Rico; cheap labour policies in South Africa, and Free Production Zones in Asia. In addition several participants were able to share their considerable knowledge of the new manufacturing sector in Brazil and Indonesia, and of conditions of women's employment in similar work in the USA and UK.

The plenary outlined the contradictions within the

1 The Internationalisation of Capital by Diane Elson and Ruth Pearson. 
world-wide process of capital accumulation which have given rise to the current phase of the production, assembling or finishing of manufactured goods in Third World countries (financed by international capital) for export to the advanced industrial countries. A distinction was made between the social relations constructing the new employment and those allocating women to these jobs. The sector of employment is being created in the LDCs because competitive conditions within these industries as a whole, the militancy of organised labour, and inflationary pressures have led to a search for cheaper labour. These jobs are superexploitative in the sense that their existence in the LDCs does not depend on superior technology or natural resources, but on lower wages, more arduous work, fewer fringe benefits and less protection for workers than exist in the developed countries (DCs). They are also highly insecure, because the industries are extremely vulnerable to fluctuations in demand in the world economy, and because it is relatively easy to relocate production to areas with even lower costs per unit of output. Some of them are also vulnerable to a protectionist response in the DCs, and others to the possibility of new technical developments which reduce the importance of the stage of production they carry out.

Although a number of analyses of these processes exist, most share a curious omission-the writers appear to consider it irrelevent that up to 90 per cent of the labour employed in the relocated production is female; none off er any adequate explanation for this. This trend to 'femmisation' poses a general problem: if cheap labour is universally abundant in LDCs why is it that firms seek to employ women rather than men? Any femmist analysis of the dynamics of the accumulation process must also try to answer a number of key questions. How universal is the tendency to employ women in manufacturing export plants? Is the same proportion of women employed in all sectors and all regions/countries of the world? Is this tendency being slowed down by the continuing slump in world trading and economic activity?

Labour costs have to be analysed in terms of nonwage factors-only then does the rationality of reallocation and exploiting women to maximise potential cost reductions become clear. In the advanced industrial countries the sexual division of labour has long permitted women to be used as a cheap and expendable labour force, and, until recently, their resistance to discriminatory and exploitative working conditions has been sporadic. Deliberately setting out to create and maintain a similar situation im the LDCs may, then, be a rational strategy for international firms.

A common explanation for using women is that they have favourable physical or psychological characteristics-manual dexterity, loyalty, willingness to accept monotonous work, little propensity to organise. Elson and Pearson argue that this view is derived from the ideological misrepresentation of gender identities, and suggest that an explanation must be sought in terms of the social relations of gender, the construction of specifically female and male social positions, and the wider social context.

Turning to the argument that such employment will give women a greater degree of independence and equality with men, Elson and Pearson suggest that structural factors, not simply attitudes of prejudice and discrimination will limit such independence. This is due to the measure of incompatibility of wage work with the particular, socially constructed, position that women occupy in the family, in which responsibilities are allocated to women, but the power to discharge these responsibilities can only be acquired through a relation of subordmation to men. The overall effect of women's employment in the capitalist labour force is thus likely to be a transformation rather than a dissolution of women's subordination.

In the discussion many participants emphasised that women's access to wage employment is temporary, unstable, insecure; that financial independence, such as it is, is very short lived; and that such employment cannot represent the path to a life-profile as income earners. Secondly it was argued that there is evidence that familial social controls on women are not relaxed even though they are earning an independent income.

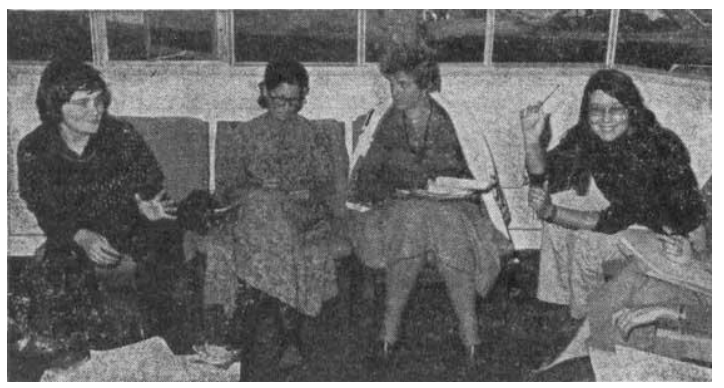

There was prolonged discussion of the implications of such employment for the control of fertility. It was suggested that the reproductive life cycle of women can be used to capitalists' 
advantage. By disclaiming any responsibility for the social cost of reproduction and child care, while at the same time operating as if such activities were incompatible with waged labour, women's reproductive role is used to reinforce their dispensibility as a workforce-individually and collectively - and has further militated against the full integration of women workers into the working class.

The four case studies all produced evidence which supported the conclusion that entry into social production was not necessarily a liberating factor for women. There were however some significant differences between them; although the women in the informal sector studied by Banerjee ${ }^{2}$ produced many of the same goods as the factory workers studied by Cardosa-Khoo, ${ }^{3} \mathrm{Heyzer}^{4}$ and Pearson $^{5}$ they worked either in small workshops or at home, and were usually older married women whereas the factory workers were unmarried and between 15-24 years old. They were also employed by local firms, whereas in the other three cases the employer was either a foreign firm, or a local firm subcontracted to a foreign firm.

The pace of work was reported to be extremely intense in all four cases, although the methods used to enforce this pace varied. In the 'putting out' system used in Calcutta, the piece rates were set so low that long hours of intensive work were necessary to secure sufficient income for family survival.

Finally a difference in the class origin and social status of employees in different types of new manufacturing industries was indicated. All the studies noted that employees in the electronics industry are now required to have higher educational standards (including competence in English) and tend to come from a higher social class than female employees in other sectors (such as textiles). Indeed Pearson suggests that the labour force in the Mexican electronics industry is constituting itself as an elite sub-group within the new class of female industrial workers, while in Malaya women electronics workers are encouraged by their bosses to consider themselves as a superior category of employees.

2 The Fruits of Development: Prickly Pears for Women Workers by Nirmala Banarjee.

3 Women and Consciousness: the case of electronics runaways in Malaysia by Jane Cardosa-Khoo.

4 Young Women and Workers in Singapore"s Labour Intensive Industries by Noeleen Heyzer.

5 The Mexican Border Industries: a case study of female wage employment in labour intensive manufacturing industries on the US-Mexican border by $\mathbf{R}$ uth Pearson.
Textile plants on the other hand recruit lower class labour at much lower levels of pay, technology and status and the methods of controlling the labour force are more direct and openly repressive than for those employed in electronics, particularly in cases where migrant workers are used. Conditions of employment, levels of technology, skills required, methods of imposing work discipline vary both within and between sectors. In the discussion it was suggested that this might result partly from technical differences between industries, partly from differences in ownership, and partly from differences in the environment in which industries operate.

In her case study of the Mexican border industries, Pearson stressed how women textile workers are constituted as a separate, secondary category of the labour force, and are not perceived as having the same rights as male workers. An important mechanism here was the assigning of women to unskilled jobs at the bottom of the factory hierarchy, with little or no prospect of promotion and extremely insecure and short-term employment. This finding was corroborated by the other two studies of textiles factories: for example in Singapore, women workers are simply 'an interchangeable commodity in the production process', they are readily dismissed and re-employed according to the ups and downs of world demand. Skill means simply "the ability to master the fastest technique of doing definite routine tasks". All three factory-based case studies found that while the vast majority of employees were women, supervisors and management, except at the lowest level, were invariably men. The subordinate position of women in society was thus reproduced within the factory.

All the case studies also showed clear differences in local pay structures. Earnings of women in the Calcutta informal sector were inhumanly low and deteriorating even further; but women in the Malaysian electronics factories earned significantly more than local women in other industries, such as textiles, and their wages compared very favourably with the local average wage for unskilled and semi-skilled male labour in manufacturing industry. In Singapore, however, the majority of female workers in textile manufacturing are clustered at the bottom of the wage structure and this was agreed to be a more common pattern.

The difference between sectors (and countries) was also refiected in the strategies used by management to increase productivity while discouraging the growth of class consciousness and organised resis- 
tance to increases in the rate of exploitation. The Asian case studies show a clearly articulated effort on the part of management in the electronics industry to control the aspirations and loyalties of their employees, by presenting the firm as the 'family' and by encouraging consumerism.

One important factor common to all four cases was the absence of virtually any legislation protecting or guaranteeing workers' rights on such matters as health and safety, job security, minimum wages, fringe benefits, trade union organisation, etc. As Banarjee pointed out, if women's employment in the 'informal sector' has not been brought inside the law (indeed, this is the key definition of the informal sector), in Free Production Zones governments have deliberately put women's employment outside the law in many important respects. In striking similarity to this was Matsepe's paper ${ }^{6}$ on South Africa which showed how the apartheid policy denied legal rights and protection to black workers and hence cheapened their labour.

Some interesting comparisons were provided by Quintero's paper ${ }^{7}$ on women in the Puerto Rican labour force. In the late 1940s US firms established subsidiaries in Puerto Rico, mainly in textiles and garments, and recruited women factory workers in large numbers. Their employment was short lived: in the following decade the industries relocated elsewhere in search of even cheaper labour. Today Puerto Rican women are in as subordinate a position as before, whether in the labour market or the family.

None of the case studies provided evidence that the women's involvement in social production had liberated them from their subordinate position within the family or in society as a whole. In some cases the women are forced to take on the double burden of domestic chores and waged work to help their families survive in rapidly deteriorating economic conditions. Moreover, their disadvantaged position is being perpetuated in the next generation; for example, in Calcutta outworking families, daughters from the age of eight or nine are kept at home to help or are sent out as domestic servants. Young sons, on the other hand, are not expected to work. Within the family, despite their economic contribution, women are in no position to question ${ }^{3}$ traditional male domina-

6 Cheap Labour Policies and their Implications for African Women in South Africa by Ivy Matsepe.

7 Capitalist Development and the Incorporation of Women into the Labour Force in Puerto Rico by Marcia Riviera Quintero. tion, exemplified clearly by their sons' privileged position.

The case study on the electronics factories in Malaysia concluded that although the young women workers were not subject to the double burden, they were still in a subordinate position to men. Older forms of subordination, operating through the social structures of rural and family life, appear to have been weakened, but had not entirely disappeared, while new forms, operating through the social structures of the factory and the city were developing. The young women workers are deliberately encouraged by management practices to perceive theselves as sex objects and to define their aspirations in terms of 'modern' luxury consumer goods rather than in terms of improving basic living conditions. The two forms of subordination may operate together to trap young women workers in situations of informal or formal sexual exploitation.

The theme of sexual exploitation of Asian women was also raised by Jayawardena, ${ }^{8}$ who used the view of women projected by a number of Asian national airlines to illustrate the way in which old forms of women's subordination are combined with new.

"In Malaysia girls are taught the gentle ways of womanhood; among them the art of providing graceful service; its a tradition you will find on MAS" (Malaysian Airlines System)

The general conclusion of the discussion was that the new manufacturing sector appears to produce new forms of subordination without entirely freeing women from the old. Policies giving support to the informal sector or Free Production Zones, or, as has been suggested by the Indian Planning Commission, investment support for industries which mainly employ women, cannot be regarded as adequate policies for dealing with women's employment problems, or for improving the position of women.

In order to formulate adequate policies we clearly need to have a greater understanding of the factors that perpetuate women's subordination after they have become industrial wage earners. One such area is the differential position of women and men with respect to wages. There was a detailed discussion on how wage levels are set as well as of the social rules surrounding the spending of wages. 8 Some Observations of the Exploitation of Asian Women by
Kumari Jayawardena. 
Dissatisfaction was expressed with both orthodox and Marxist explanations of wage determination. As for spending the wage, more information is needed on what proportion of income unmarried women workers keep for themselves and what proportion they send to their families, and on establishing whether, as some examples suggest, young men wage earners have different patterns of expenditure and obligations. Participants discussed the evidence that despite their crucial contributions to the family budget, neither married nor unmarried women appear to be freed from their position of subordination within the family. This suggests that a more sophisticated understanding of relations within the family is still needed.

Turning to the new manufacturing industries, participants discussed how the relocation of jobs from the First World to the Third World had taken place. Two hypotheses were put forward. The first was that the subordinate position of women in the First World made it easier to relocate women's traditional jobs than men's. The second was that the promotion of forms of employment which are outside the purview of much labour legislation was made easier by women's subordinate social position-if the prospective employees were male such policies would meet with more vigorous opposition. Both hypotheses would require an investigation of policies of trade unions and governments in both the First and Third World.

Lastly, there was a lengthy discussion of the ways in which use of women in waged labour is made compatible with their reproductive roles. In many situations women with children are not employed (marriage is a justification for immediate dismissal from employment). In others, women depend on the extended family network to share childcaring. This led to a discussion of the female centredness of mutual aid networks and the implications of this were stressed, in particular for the survival strategies of poor urban women, who are often household heads.

It was noted that when employment policies encourage female wage participation government policies often aim at discouraging fertility. Ideologies of modernity, often incorporating feministsounding rhetoric, ỵere promoted to discourage either early marriage or large families. At the same time stress is laid on free-choice: several participants argued that this ideology serves to strip workers of their defences in the face of shifts in accumulation strategies.

\section{Agribusiness and the impact of commercial agricultural production and large scale technical change in agriculture.}

The common theme of these papers was the need to analyse the relation between capital accumulation and the forms which it takes in the agricultural economy, and the transformations in the rural household and the position of women within it.

The most general statement of this approach is found in the paper by Leon de Leal and Deere ${ }^{9}$

"The process of change encompassed by the development of capitalist social relations in the rural areas provides the analytical framework through which to view the changes in the form of incorporation of the peasantry to the wider economy, its impact on the peasant household labour process, and, consequently, on the division of labour by sex".

This study was thus concerned to work downwards, in theoretical terms, from national (or international) processes to local change. None of the other papers operated on this level of generality, nor did they attempt to specify in such precise terms the theoretical framework in which the case studies were set. The three papers on estate farming (Stoler, ${ }^{10}$ Martinez-Alier, ${ }^{11}$ Mackintosh, ${ }^{12}$ ) were concerned with the interaction between work on the estate and other sections of the rural economy, while those by Palmer ${ }^{13}$ and Halpern ${ }^{14}$ discuss the impact on women of two different types of technical change brought about through the activities and mediation of international agencies.

In the first set of papers on estate farming four key areas of analysis were discussed:

1 The sexual division of labour in estate work and wage differentials by sex Mackintosh documented the evolution of sex-typed job categories on an estate in Senegal and the attribution to women's jobs of lower pay and poorer conditions of work. On the Saõ Paulo coffee plantations women also carry out the most demanding jobs for

\footnotetext{
9 The Study of Rural Women and the Development of Capitalism in Colombian Agriculture by Magdalena Leon de Leal and Carmen Diana Deere.

10 Proletariats and Planters by Ann Stoler.

11 The Subordination of Women and Productive Labour by Verena Martinez-Alier.

12 Sexual Contradiction and Labour Confict on a West African Estate Farm by Maureen Mackintosh.

13 Women and the Green Revolution by Ingrid Palmer.

14 Labour Displacement Among Rural Women in Bangladesh by Peri Halpern.
} 
piece rates, whereas men rarely work for a piece rate.

2 The use of family labour by the estate Martinez-Alier describes the old colonate system in the Saõ Paulo plantations whereby an estate worker would contract the labour of the whole family to cultivate a specific area of land. Since the 1940 s the colonos have been gradually evicted from their subsistence plots and all family members have been proletarianised.

The women interpret this as a shift from 'working for themselves' to 'working outside' for a wage. In contrast, in the Sumatra oil palm estates discussed by Stoler, unwaged child labour is increasingly being used. This additional labour power appears in estate calculations as increased labour productivity per worker.

3 Casual labour Stoler also highlights the increasing use of casual labour in the last decade, and the predominant position of women within this section of the labour force. Increasing casualisation and use of female labour is also described by Mackintosh. Leon de Leal and Deere suggest that women function as a labour reserve for capital in all four of the regions they studied, despite regional differences in economic and social structure.

4 The labour process All writers argued that a feature of the new type of agribusiness is that quality and regularity, and hence control of the labour process, has become very important. Management's strategy towards the female labour force has to be understood in this light. Reducing production costs also means that women tend to be used for the highly labour-intensive tasks on estates: if mechanisation occurs they are the first to be laid off.

A theme of all the papers was the effect of the sexual division of labour within the household on women's participation in wage work. Deere ${ }^{15}$ shows that under the Peruvian hacienda system, the amount of labour and services each male tenant had to supply determined the level of his womenfolk's participation in agricultural production. Stoler in turn traced the way in which varying availability of land to the estate workers both affected women's participation in the estate labour force (as did the overall letel of wages) and the shift to casual labour.

15 Differentiation of the Peasantry and Family Structure: $A$ Peruvian Case Study by Carmen Diana Deere.
A second point of discussion was the link between women's lesser position in the household and their willingness to accept lower wages. Martinez-Alier reported some interpretations of this from her interviews with women on the coffee plantations:

"Women's work is defined as subsidiary in the maintenance of the family, her primary responsibility being domestic. . ." and "Women work because necessity obliges them to, men work because they are men".

The fact that men's and women's incomes are viewed differently in the household, and cannot simply be treated as a common pool, was a major theme of the conference. Palmer referred to it when she argued that a higher income level for the male household head may not benefit women. Her paper raised the question of what types of changes in the agricultural economy reinforce the dominance of the male within the household. Incorporation into the market, and credit institutions, by establishing the man as the intermediary between the household and the new market institutions, may do just this.

The significance of inter-household relations was also stressed by Stoler who argued that the women in Sumatran villages on the plantation peripheries were in a weaker position than women in Javanese villages. These plantation villages have a fragmented, individualised structure; the women within them lose control over both child labour and trade, as well as losing the benefits of a complex set of inter-household mutual aid relations.

The fact that much work which is typically female is unpaid was raised several times; and in a number of papers the importance of distinguishing between household work and unremunerated work was raised as both a theoretical and political problem. This was especially clear in Palmer's discussion of the implications of agricultural intensification, whereby overall paid employment may diminish, while unpaid labour is intensified. While hired women may be made redundant by mechanisation, the work of women in families with land may be increased. In the discussion the general point was made that transformations in waged work may have unforeseen and as yet little studied effects on the organisation of unpaid work carried out within the relations of the family and household.

The discussion of two papers more explicitly concerned with policy raised a number of contentious issues regarding the best way in which women can act to strengthen their position. Although the point 
was again made that drawing women into socialised production is not necessarily liberating, nonetheless many participants pointed to the importance of women becoming involved in a social context beyond the home as a pre-condition to their questioning their position. Others argued that this should not discount the possibility of organisation and action by women within the home. This immediately provoked the question of whether women organise without reference to their class position. The material conflict of interests among women of different social strata was highlighted by Halpern's paper on the impact of mechanising rice processing in Bangladesh. This technical innovation, she suggests, will bring a loss of livelihood for large numbers of the poorest rural women, now hired to process the rice of better-off women who would welcome the labour-saving mills.

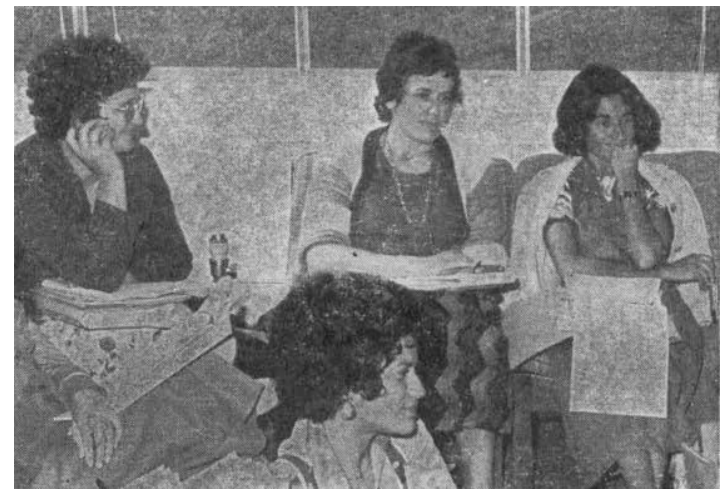

Palmer suggested that women's work cooperatives should be established to give women some independent economic and social base, arguing for inclusion of women of households with land as well as those without it. Many participants doubted the feasibility of such a strategy, and made the point that existing exchange labour systems generally operate only between people with land, in the context of a network of other kin-based relations, and that such cross-class organisations would go against existing systems of individual patronage.

The suggestion that women should organise to secure better conditions for themselves raised the question of militancy. Mackintosh's paper, which discussed the differen attitudes and reactions of men and women workers during a strike, concluded that women are no less militant than men, nor are they "less political". While women's political attitudes may differ from those of men, they may pursue certain issues to their end with greater determination.
A critical factor in women's capacity for struggle is the degree to which they are isolated, and the ways in which their relationships are mediated and controlled by males from their household. Halpern's paper indicated that the seclusion of women means that poor women are subject to the fate of their households: if economic differentiation becomes worse, they have no defences against increasing poverty and destitution. In such a situation projects for women may be more easily coopted by rich households than in a society where women from different households can associate freely. In discussing policy options for women, the need to challenge the idea of women as a problem-for someone else-was endorsed by all participants. Programmes for women all too of ten are based on the welfarist notion that women need to be helped-are somehow less able to cope -than on an analysis of the structural factors underlying their disadvantageous position. A classic example of this are the many policies and programmes which seek to reinforce the position of the male as the household head and chief breadwinner-the assumption being that all household members will benefit equally from his primacy. In part this is due to a second assumption: that different roles for the genders are a result and an expression of complementarity-equal but different. Should it not rather be asked whether different roles for men and women are a result and an expression of sexual inequality? If this is the case can any project embodying such role differentiation be a viable basis for equality?

Other ways in which agencies may either unwittingly or deliberately endorse institutions which are oppressive to women were also discussed: for example the institutionalisation of lower wages for women in women's projects.

The conflicts and contradictions inherent in the conception women have of the marriage relation, and the obligations it can or should impose, was brought out in several papers. "Marriage is now a sport; husbands do not provide for their wives, we provide for ourselves" a Brazilian woman was reported as saying. For many women, working outside the home often merely doubles their burden of work, and they reasonably therefore "endorse the very institution which assigns them a subsidiary position in production" (MartinezAlier).

A possible universal trend to matrifocality (femalecentred households) and to female headed households was briefly discussed in this context. Does growing poverty and males' lesser social responsi- 
bility for the care of children combine to make men abondon their families? Or does increased demand for women's labour in conditions of growing poverty make women unwilling to shoulder not only the double burden of waged work and child-care but the triple burden of servicing an adult who is socially conditioned to demand it without reciprocating? 